DOI: http://dx.doi.org/10.33846/ghs5317

\title{
Pengaruh Senam Diabetes Terhadap Penurunan Kadar Gula Darah Pasien Diabetes Mellitus di Puskesmas Bah Kapul Pematangsiantar Tahun 2019
}

\author{
Romauli Pakpahan (koresponden) \\ (Dosen Program Studi Ilmu Keperawatan, Universitas Efarina) \\ Marlon Sijabat \\ (Dosen Program Studi IImu Keperawatan, Universitas Efarina)
}

\begin{abstract}
This study aims to determine the effect of diabetes gymnastics on the decrease in blood sugar levels of diabetic patients at the puskesmas Bah Kapul Pematangsiantar. This research was conducted in Juni - Agustus 2017, the design of this study was comparative. The sample size in this study were 21 respondents obtained by total population sampling. Data were obtained through questionnaires, interviews and direct capillary blood sampling of respondents to then measured blood sugar levels by using glucose meter. Data analysis was done gradually including descriptive and paired samples $t$ test. The results of this study showed that before doing gymnastics in the first week of the average blood sugar levels of respondents was $272.4 \mathrm{mg} / \mathrm{dl}$ and after doing gymnastics in the fourth week of the average blood sugar levels of respondents was $257.04 \mathrm{mg} / \mathrm{dl}$, blood sugar of $15.36 \mathrm{mg} / \mathrm{dl}$. Result of paired samples t-test significantly decrease blood sugar level at respondent with $p$ value of 0,041 . This means that there is influence of diabetes gymnastics to the decrease of blood sugar level of diabetic patient. It is expected for health service to be a motivator and provide intensive counseling for people with diabetes mellitus to do gymnastic gymnastics routine to lower blood sugar level and prevent complication of diabetes mellitus.
\end{abstract}

Keywords: gymnastics diabetes; blood sugar

\section{PENDAHULUAN}

Diabetes mellitus merupakan suatu kelompok penyakit metabolik dengan karakteristik hiperglikemia yang terjadi karena kelainan sekresi insulin, kerja insulin atau kedua-duanya (ADA, 2010), bersifat kronik dan disertai komplikasi kronik ataupun akut.

Diabetes mellitus merupakan penyakit degeneratif yang memerlukan penanganan yang tepat dan serius. Penyakit tersebut akan membawa sebagian komplikasi yang serius seperti penyakit jantung, stroke, disfungsi ereksi, gagal ginjal dan kerusakan sistem syaraf. Menurut estimasi International Diabetes Federation (IDF) terdapat 194 juta penduduk Indonesia menderita Diabetes Mellitus pada tahun 2003. WHO memprediksi data Diabetes Mellitus akan meningkat menjadi 333 juta dalam 25 tahun mendatang (Soegondo \& Sidartawan, 2009).

Senam adalah suatu kegiatan yang di lakukan untuk meningkatkan kekuatan sendi dan keindahan tubuh dengan tujuan membentuk dan dan mengembangkan pribadi secara harmonis. Senam diabetes mellitus bertujuan memperbaiki kesegaran kardiovaskuler yaitu jantung,pembulupembulu darah, pernafasan, dan sirkulasi darah.

Tujuan penelitian ini adalah untuk mendapat gambaran pengaruh senam diabetes terhadap penurunan kadar gula darah pasien Diabetes Mellitus di Puskesmas Bahkapul.

\section{METODE}

Desain penelitian yang digunakan dalam penelitian ini adalah komparatif yang bertujuan mengidentifikasi pengaruh senam diabetes terhadap penurunan kadar gula darah pasien diabetes di Puskesmas Bahkapul. Penelitian ini dilakukan di Puskesmas Bahkapul yang akan dilaksanakan pada Juni - Agustus 2017. Populasi dalam penelitian ini adalah keseluruhan penderita diabetes melitus yang mengikuti program senam diabetes di Puskesmas Bahkapul yaitu pada bulan Juli-Agustus 2017 sebanyak 61 orang). Dalam penelitian ini pengambilam sampel dilakukan dengan cara total sampling artinya seluruh penderita diabetes yang ikut program senam diabetes di Puskesmas Bahkapul sebanyak 30 orang digunakan sebagai sampel, namun karena 9 orang yang tidak bersedia hadir setiap minggu dengan alasan tidak ada yang rutin mengantar maka sampel dalam penelitian ini yaitu 21 orang.

HASIL

Dari hasil penelitian yang dianalisis dengan menggunakan paired samples t-test secara signifikan terjadi penurunan kadar gula darah pada responden dengan nilai $p<0,05$ yaitu 0,041 . Hal ini berarti bahwa dengan melakukan senam secara rutin secara langsung dapat menurunkan kadar gula darah. 
GLOBAL HEALTH SCIENCE,

Table 1. Deskriptif Karakteristik Responden Menurut Umur

\begin{tabular}{|c|c|c|c|c|c|c|}
\hline & Mean & Median & Modus & Min & Max & SD \\
\hline Umur & 53 & 54 & 48 & 39 & 63 & 7.092 \\
\hline
\end{tabular}

Tabel 2. Karakteristik Responden Menurut Jenis Kelamin, Suku, Agama, Pendidikan, dan Pekerjaan

\begin{tabular}{|l|c|c|}
\hline Karakteristik & Frekuensi & Persentase \\
\hline $\begin{array}{l}\text { 1. Jenis Kelamin } \\
\text { Laki-laki }\end{array}$ & 8 & $38.10 \%$ \\
Perempuan & 13 & $61.90 \%$ \\
\hline 2. Suku & 10 & $47.62 \%$ \\
Batak & 3 & $14.29 \%$ \\
Melayu & 4 & $19.05 \%$ \\
Jawa & 3 & $14.29 \%$ \\
Aceh & 1 & $4.79 \%$ \\
Minang & 13 & $61.90 \%$ \\
\hline 3. Agama & 8 & $38.10 \%$ \\
Islam & & \\
Kristen & 6 & $28.57 \%$ \\
\hline 4. Pendidikan & 10 & $47.62 \%$ \\
Perguruan Tinggi & 4 & $19.05 \%$ \\
SMA & 1 & $4.76 \%$ \\
SMP & & \\
SD & 15 & $71.43 \%$ \\
\hline 5. Pekerjaan & 6 & $28.57 \%$ \\
PNS & & \\
Wiraswasta & \\
\hline
\end{tabular}

Dari tabel 1 dan 2 dapat dilihat deskripsi karakteristik demografi responden terdiri dari usia, jenis kelamin, suku, pendidikan, dan pekerjaan responden. Hasil penelitian menunjukkan bahwa karakteristik responden sebanyak 21 responden, pada karakteristik umur nilai mean $=53$, median $=54$ dan modus $=48$, umur terendah yaitu39 tahun dan umur tertinggi 63 tahun dan $\mathrm{SD}=7,092$. Mayoritas jenis kelamin responden adalah perempuan (61,9\%), responden bersuku batak (47,6\%), sebagian besar responden beragama islam $(61,90 \%)$. Responden kebanyakan berlatar belakang pendidikan SMA (47,62\%), dan sebagian besar responden bekerja sebagai pegawai negeri sipil $(71,4 \%)$.

Tabel 3. Hasil pemeriksaan kadar gula darah pasien diabetes sebelum dan sesudah senam diabetes dari minggu 1 - minggu 4

\begin{tabular}{|c|c|c|c|c|c|c|c|c|c|c|c|c|}
\hline \multirow{2}{*}{$\begin{array}{c}\text { Res- } \\
\text { Pon } \\
\text { den }\end{array}$} & \multicolumn{2}{|c|}{ KGD Minggu ke 1} & \multirow[b]{2}{*}{$\%$} & \multicolumn{2}{|c|}{ KGD Minggu ke 2} & \multirow[b]{2}{*}{$\%$} & \multicolumn{2}{|c|}{ KGD Minggu ke 3} & \multirow[b]{2}{*}{$\%$} & \multicolumn{2}{|c|}{ KGD Minggu ke 4} & \multirow[b]{2}{*}{$\%$} \\
\hline & \begin{tabular}{|c} 
Sebe- \\
hum \\
senam
\end{tabular} & $\begin{array}{l}\text { Sestr } \\
\text { dah } \\
\text { senam }\end{array}$ & & $\begin{array}{l}\text { Sebe- } \\
\text { hun } \\
\text { senam }\end{array}$ & $\begin{array}{l}\text { Sesu- } \\
\text { dah } \\
\text { senam }\end{array}$ & & $\begin{array}{c}\text { Sebe- } \\
\text { hum } \\
\text { senam }\end{array}$ & $\begin{array}{l}\text { Sesu- } \\
\text { dah } \\
\text { senam }\end{array}$ & & $\begin{array}{l}\text { Sebe- } \\
\text { hum } \\
\text { senam }\end{array}$ & $\begin{array}{c}\text { Sesu- } \\
\text { dah } \\
\text { senam }\end{array}$ & \\
\hline 1 & 225 & 217 & 1,8 & 277 & 271 & 1,1 & 201 & 193 & 2 & 237 & 235 & 0,4 \\
\hline 2 & 179 & 167 & 3,5 & 171 & 166 & 1,5 & 135 & 132 & 1,1 & 146 & 140 & 2,1 \\
\hline 3 & 187 & 185 & 0,5 & 196 & 194 & 0,5 & 180 & 174 & 1,7 & 178 & 165 & 3,1 \\
\hline 4 & 326 & 320 & 0,9 & 294 & 282 & 2,1 & 365 & 365 & 0 & 338 & 334 & 0,1 \\
\hline 5 & 246 & 231 & 3,1 & 234 & 227 & 1,5 & 242 & 231 & 2,3 & 194 & 193 & 0,2 \\
\hline 6 & 165 & 154 & 3,5 & 178 & 177 & 0,3 & 182 & 179 & 0,8 & 184 & 176 & 2,2 \\
\hline 7 & 326 & 329 & -0 & 316 & 312 & 0,6 & 314 & 301 & 2,1 & 349 & 321 & 4,2 \\
\hline 8 & 186 & 191 & -1 & 204 & 207 & - & 164 & 156 & 2,5 & 155 & 151 & 1,3 \\
\hline 9 & 190 & 195 & -1 & 205 & 209 & -1 & 173 & 171 & 0,6 & 167 & 160 & 2,1 \\
\hline 10 & 298 & 287 & 1,9 & 286 & 281 & 0,9 & 226 & 234 & -2 & 274 & 272 & 0,4 \\
\hline 11 & 194 & 190 & 1 & 175 & 161 & 4,2 & 152 & 142 & 3,4 & 178 & 171 & 2 \\
\hline 12 & 523 & 514 & 0,9 & 496 & 498 & -0 & 478 & 469 & 0,9 & 461 & 454 & 0,8 \\
\hline 13 & 157 & 1 & -1 & 1 & 1 & 0,3 & 154 & 156 & -1 & 151 & 47 & 3 \\
\hline 14 & 264 & 250 & 2,7 & 254 & 266 & -2 & 249 & 237 & 2,5 & 177 & 179 & $-0,6$ \\
\hline 15 & 304 & 307 & -1 & 381 & 363 & 2,4 & 364 & 361 & 0,4 & 377 & 358 & 2,6 \\
\hline 16 & 317 & 302 & 2,4 & 347 & 351 & -1 & 296 & 298 & -0 & 304 & 283 & 3,6 \\
\hline 17 & 445 & 427 & 2,1 & 409 & 391 & 2,3 & 494 & 472 & 2,3 & 436 & 432 & 0,5 \\
\hline 18 & 262 & 266 & -1 & 224 & 2 & -1 & 257 & 263 & -1 & 278 & 274 & 0,7 \\
\hline 19 & 304 & 301 & 0,5 & 309 & 301 & 1,3 & 320 & 317 & 0,5 & 307 & 304 & 0,5 \\
\hline 20 & 283 & 282 & 0,2 & 271 & 271 & 0 & 278 & 273 & 0,9 & 279 & 276 & 0,5 \\
\hline 21 & 341 & 345 & -1 & 347 & 349 & -0 & 365 & 369 & -1 & 370 & 373 & $-0,4$ \\
\hline
\end{tabular}


Dari tabel 3 dapat dilihat bahwa 21 responden melakukan senam pada minggu-1 sampai minggu-4. Rata-rata nilai kadar gula darah responden pada minggu pertama sebelum senam $=272,5$, nilai minimum $=157$ maximum $=523$ dengan standart deviasi 92,7 , rata-rata sesudah senam $=267,7$, nilai minimum $=154$, maximum $=514$ dan standart deviasi 91,0. Pada minggu kedua rata-rata sebelum senam $=273,4$, nilai minimum $=167$, maximum $=456$ dengan standart deviasi $=87,8$, ratarata sesudah senam $=270,0$, minimum $=161$, maximum $=498$ dan standart deviasi $=86,6$. Pada minggu ketiga rata-rata sebelum senam $=266,1$, nilai minimum $=135$, maximum $=494$ dan standart deviasi 103,7 , rata-rata sesudah senam $=261,5$ nilai minimum $=132$, maximum $=472$ dan standart deviasi $=102,1$. Pada minggu keempat rata-rata sebelum senam $=263,8$ dengan nilai minimum $=146$, maximum $=461$ dan standart deviasi $=97,8$ dan rata-rata sesudah senam $=257,0$ dengan nila minimum $=140$, maximum $=454$ dan standart deviasi $=96,5$.

Tabel 4. Perbedaan Kadar Gula Darah Pasien Diabetes Sebelum dan Sesudah Senam Minggu 1 di Puskesmas Bah Kapul, Pematangsiantar

\begin{tabular}{|c|c|c|c|c|}
\hline KGD sebelum dan sesudah & Mean & Std. Deviation & $\mathrm{T}$ & $p$-value \\
\hline Minggu I & 4.81 & 7.737 & 2.849 & 0.01 \\
\hline Minggu II & 3.333 & 7.696 & 1.985 & 0.061 \\
\hline Minggu III & 4.571 & 7.117 & 2.943 & 0.008 \\
\hline Minggu IV & 6.762 & 7.622 & 4.066 & 0.001 \\
\hline
\end{tabular}

Dari tabel 4 dapat dilihat bahwa perbedaan kadar gula darah sebelum dan sesudah senam pada minggu pertama diperoleh nilai mean $=4,810$ dengan Std.deviasi $=7,737, t=2,849$ dan nilai $p$ sebesar 0,010. Untuk memperjelas perbandingan kadar gula darah sebelum dan sesudah senam dapat dilihat pada gambar 1 .

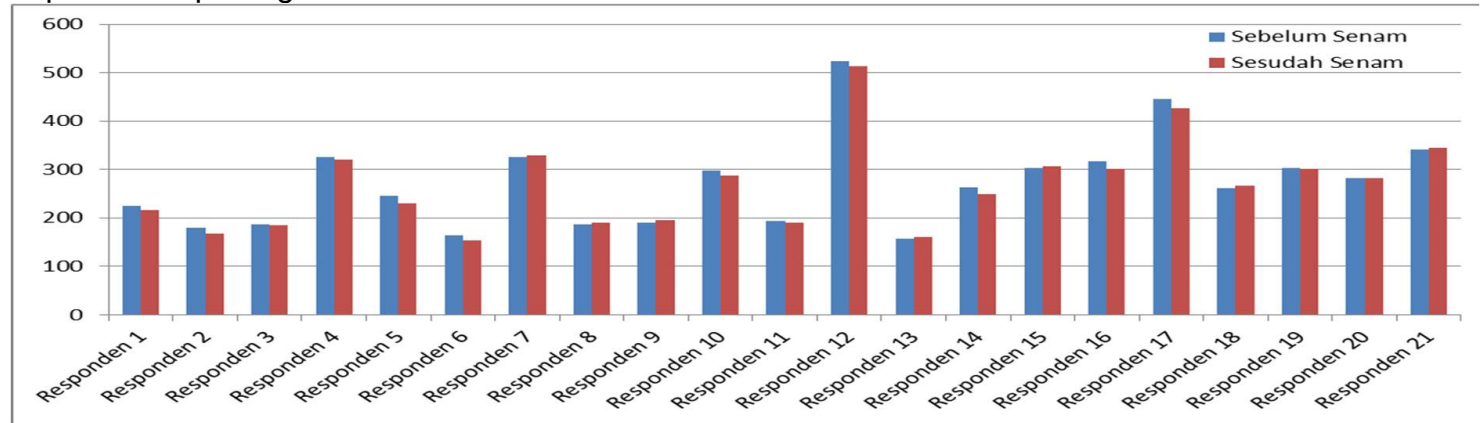

Gambar 1. Kadar gula darah sebelum dan sesudah senam mingu pertama di Puskesmas Bah Kapul Pematangsiantar Tabel dapat dilihat diagram di bawah ini.

Dari tabel 4 dapat dilihat bahwa perubahan kadar gula darah sebelum dan sesudah senam pada minggu kedua diperoleh nilai mean $=3,333$ dengan std. deviasi $=7,696, t=1,985$ dan nilai $p$ sebesar 0,061 . Untuk memperjelas perbandingan kadar gula darah sebelum dan sesudah senam dapat dilihat pada gambar 2 .

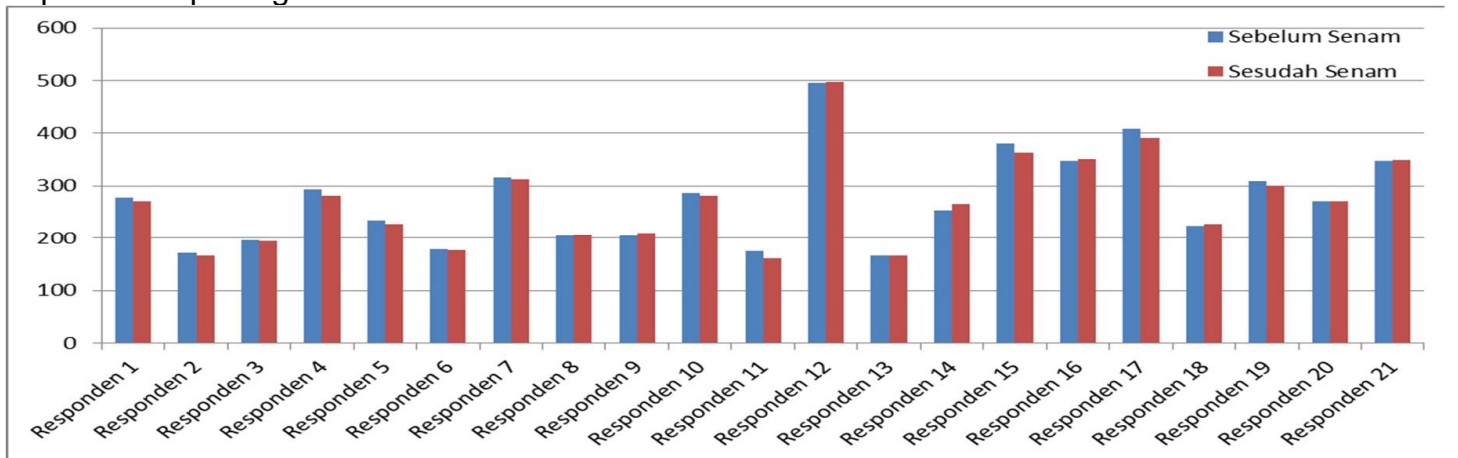

Gambar 2. Kadar gula darah sebelum dan sesudah senam minggu kedua di Puskesmas Bah Kapul, Pematangsiantar

Dari tabel 4 dapat dilihat bahwa perubahan kadar gula darah sebelum dan sesudah senam minggu 3 diperoleh nilai mean $=4,571$ dengan std. deviasi $=7,117, t=2,943$ dan nilai $p=0,008$. Untuk memeperjelas perbanding an kadar gula darah sebelum dan sesudah senam dapat dilihat pada gambar 3. 


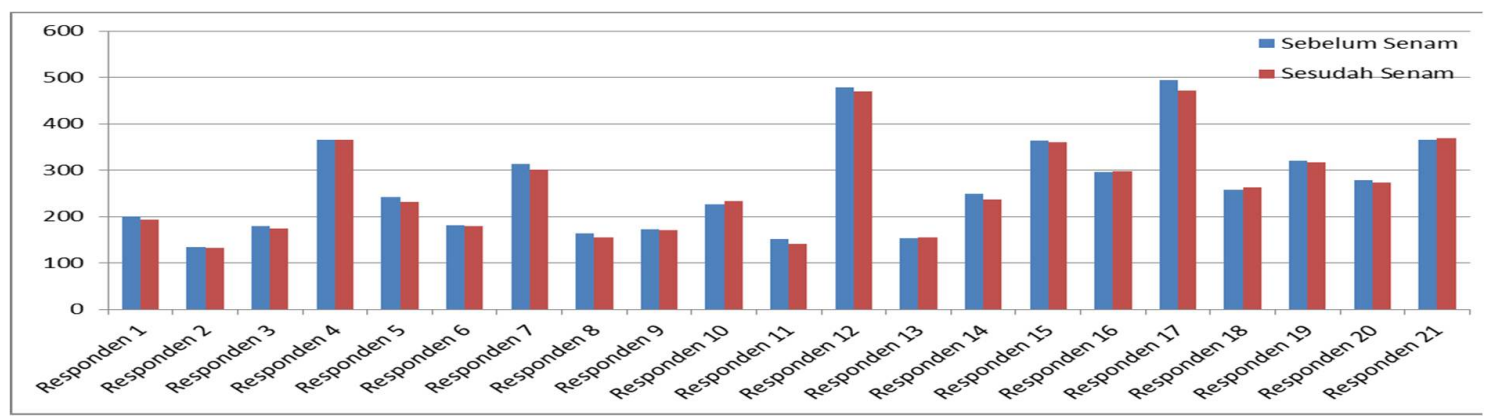

Gambar 3. Kadar Gula Darah sebelum dan sesudah senam minggu ke tiga di Puskesmas Bah Kapul, Pematangsiantar

Dari tabel 4 dapat di lihat bahwa perbedaan kadar gula darah sebelum dan sesudah senam pada minggu keempat diperoleh nilai mean $=6,762$ dengan std. deviasi $=7,622, t=4,006$ dan nilai $p$ $=0,001$. Untuk memperjelas perbandingan kadar gula darah sebelum dan sesudah senam dapat dilihat gambar 4.

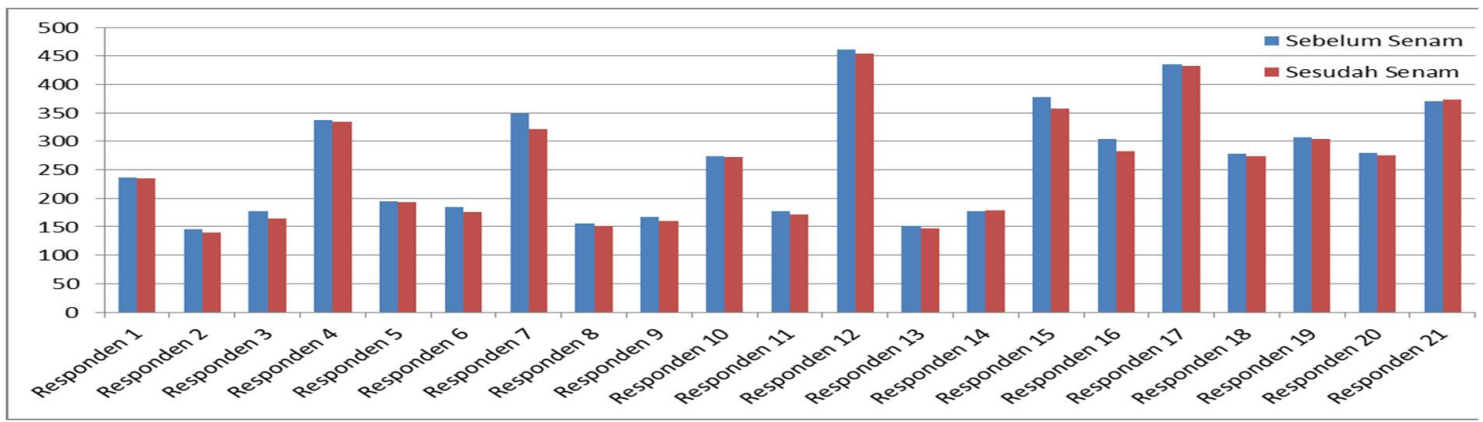

Gambar 4. Kadar gula darah sebelum dan sesudah senam minggu keempat di Puskesmas Bah Kapul, Pematangsiantar

Tabel 5. Perbedaan Kadar Gula Darah Sebelum Senam Minggu-1 dan Sesudah Senam Minggu-4 di Puskesmas Bah Kapul, Pematangsiantar

\begin{tabular}{|c|c|c|c|c|}
\hline Variabel & Mean & Std. Deviation & $\mathrm{T}$ & $p$-value \\
\hline KGD sebelum dan sesudah & 15.429 & 32.403 & 2.182 & 0.041 \\
\hline
\end{tabular}

Pada tabel diatas terlihat perbedaan antara pengukuran sebelum dan sesudah adalah 15,429 dengan Std deviasi $=32,403$ dan nilai $p=0,041$. Hasil ini menunjukkan bahwa kadar gula darah sebelum senam (minggu pertama) dan sesudah senam (minggu ke empat) memiliki perbedaan yang signifikan/bermakna $(p<0,05)$. Dari hasil tersebut diketahui bahwa ada pengaruh senam diabetes terhadap penurunan kadar gula darah. Untuk memperjelas perbandingan kadar gula darah sebelum senam pada minggu pertama dan sesudah senam pada minggu keempat dapat dilihat paga gambar 5 .

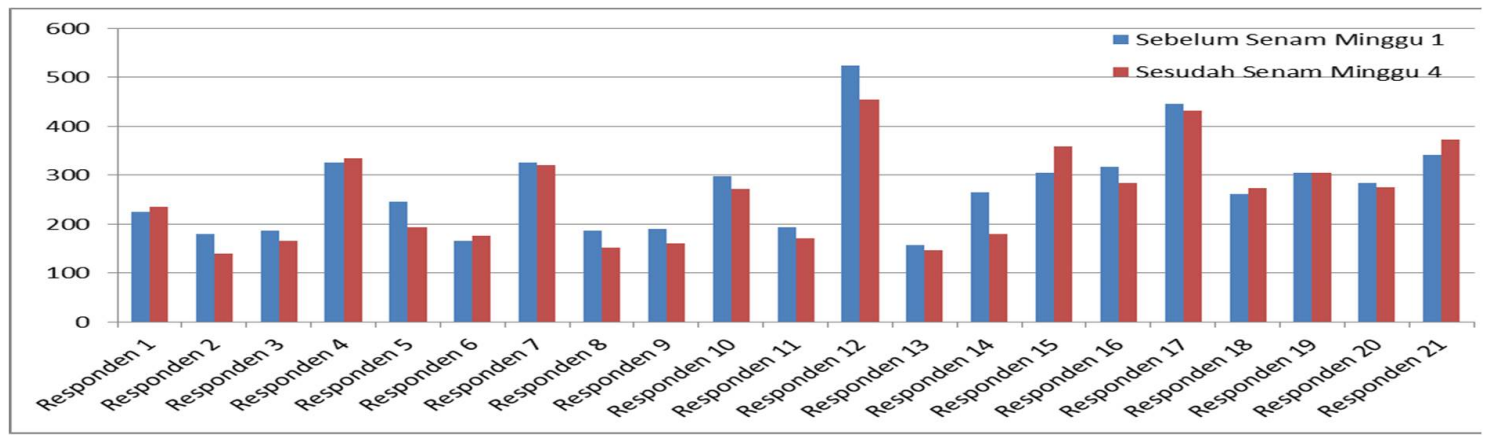

Gambar 5. Kadar gula darah sebelum senam minggu pertama dan sesudah senam minggu keempat di Puskesmas Bah Kapul, Pematangsiantar 


\section{PEMBAHASAN}

Berdasarkan hasil penelitian di atas, peneliti dapat menjawab pertanyaan mengenai pengaruh senam diabetes terhadap penurunan kadar gula darah pada pasien diabetes. Dari hasil pemeriksaan kadar gula darah sebelum melakukan dan setelah melakukan senam setiap minggunya terjadi perubahan kadar gula darah. Pada minggu pertama, dari 21 responden yang melakukan senam 14 responden mengalami penurunan kadar gula darah dengan rata-rata penurunan $9 \mathrm{mg} / \mathrm{dl}$ dan 7 responden lainnya mengalami peningkatan kadar gula darah rata-rata $4 \mathrm{mg} / \mathrm{dl}$. Berdasarkan hasil uji paired t-test secara signifikan terdapat penurunan kadar gula darah setelah melakukan senam pada responden dengan nilai $p<0,05$ yaitu 0,01 .

Berat badan yang berlebihan bisa menyebabkan Diabetes tingginya kadar gula darah, karena jalan insulin yang hendak menyebarkan gula-gula kedalam sel terhalangi akibatnya gula menumpuk begitu saja(Retno,2012. Pengaruh senam diabetes terhadap otot-otot akan berpengaruh terhadap penurunan kadar glukosa darah, dikarenakan reseptor insulin menjadi bertambah dengan bertambahnya otot tersebut, yang akhirnya tidak terjadi penumpukan gula yang berlebihan dalam darah. Karena kalau jumlah insulin yang dihasilkan pankreas lebih sedikit dari pada jumlah makanan yang kita makan memiliki jumlah kandungan gula yang lebih tinggi, sehingga kadar gula darah dalam tubuh tidak terkontrol yang bisa menyebabkan tingginya kadar gula darah(Retno,2012).

Menurut uraian diatas dapat dipahami latihan senam diabetes dapat meningkatkan efisiensi kerja jantung karna membutuhkan kekuatan.Dari hasil penelitian pada minggu pertama responden belum efektif melakukan senam Diabetes sehingga dari 21 responden yang melakukan senam ada 7 responden tidak mengalami kenaikan kadar gula darah. 7 Responden yang mengalami kenaikan kadar gula darah dikarenakan tidak dapat mengikuti gerakan-gerakan senam diabetes sesuai dengan standart denam Diabetes.

Pada minggu kedua hasil pemeriksaan gula darah responden juga mengalami perubahan setelah melakukan senam, 13 responden mengalami penurunan kadar gula darah dengan rata-rata penurunan $7 \mathrm{mg} / \mathrm{dl}$, dan 7 responden mengalami peningkatan kadar gula darah dengan rata-rata peningkatan $4 \mathrm{mg} / \mathrm{dl}$ sedangkan 1 responden lainnya tidak mengalami perubahan kadar gula darah setelah melakukan senam. Berdasarkan hasil uji paired t-test secara signifikan tidak terdapat penurunan kadar gula darah pada responden setelah melakukan senam, hal ini dapat dilihat dengan nilai $p=0,061 \quad(p>0,05)$. Hal ini mungkin saja dapat terjadi karena responden mengkonsumsi makanan yang dapat meningkatkan kadar gula darah 2 jam sebelum pemeriksaan atau responden tidak melakukan/mengikuti instruktur senam dengan benar sehingga tidak terjadi penurunan kadar gula darah secara signifikan/bermakna.

Pada minggu ketiga 15 responden mengalami penurunan kadar gula darah dengan rata-rata penurunan $8 \mathrm{mg} / \mathrm{dl}$, dan 5 responden mengalami peningkatan kadar gula darah dengan rata-rata peningkatan $5 \mathrm{mg} / \mathrm{dl}$ sedangkan 1 responden lainnya tidak mengalami perubahan kadar gula darah setelah melakukan senam. Berdasarkan hasil uji paired t-test secara signifikan terdapat penurunan kadar gula darah pada responden setelah melakukan senam pada minggu ketiga. Hal ini dibuktikan dengan nilai $p<0,05$ yaitu $p=0,008$.

Sedangkan pada minggu keempat 19 responden mengalami penurunan kadar gula darah dengan rata-rata penurunan $8 \mathrm{mg} / \mathrm{dl}$ dan 2 responden mengalami peningkatan kadar gula darah dengan rata-rata peningkatan $2 \mathrm{mg} / \mathrm{dl}$ setelah melakukan senam. Berdasarkan hasil uji paired t-test secara signifikan juga terdapat penurunan kadar gula darah pada responden setelah melakukan senam, hal ini dibuktikan dengan nilai $p<0,05$ yaitu $p=0,01$.

Setelah melakukan senam selama 4 minggu 14 responden mengalami penurunan kadar gula darah dengan rata-rata penurunan $32 \mathrm{mg} / \mathrm{dl}, 6$ responden mengalami peningkatan kadar gula dengan rata-rata peningkatan $21 \mathrm{mg} / \mathrm{dl}$ dan 1 responden lainnya tidak mengalami perubahan kadar gula darah.

Sebelum melakukan senam pada minggu pertama rata-rata kadar gula darah responden yaitu $272,4 \mathrm{mg} / \mathrm{dl}$ dan setelah melakukan senam pada minggu keempatrata-rata kadar gula darah responden yaitu $257,04 \mathrm{mg} / \mathrm{dl}$, terjadi penurunan kadar gula darah sebesar 15,36 mg/dl.

Dari hasil penelitian yang dianalisa dengan menggunakan uji paired t-test secara signifikan terjadi penurunan kadar gula darah pada responden dengan nilai $p<0,05$ yaitu 0,041 . Hal ini berarti bahwa dengan melakukan senam secara rutin secara langsung dapat menurunkan kadar gula darah.

\section{KESIMPULAN}

Berdasarkan hasil uji paired t-test, setelah melakukan senam pada minggu pertama secara signifikan terdapat penurunan kadar gula darah pada responden dengan nilai $p<0,05$ yaitu $p=0,01$. Sedangkan pada minggu kedua diperoleh nilai $p>0,05$ yaitu $p=0,061$ yang artinya tidak terdapat 
penurunan kadar gula darah yang bermakna. Hasil uji paired t-test pada responden setelah melakukan senam pada minggu ketiga menunjukkan nilai $p<0,05$ yaitu $p=0,008$ yang artinya terdapat penurunan kadar gula darah yang bermakna, sedangkan pada minggu keempat hasil uji paired t-test menunjukkan nilai $p<0,05$ yaitu $p=0,001$, hal ini berarti juga terdapat penurunan kadar gula darah yang bermakna.

Secara keseluruhan hasil uji paired t-test pada pemeriksaan kadar gula darah sebelum senam minggu pertama dan sesudah senam minggu keempat menunjukkan nilai $p<0,05$ yaitu $p=0,041$, hal ini berarti terdapathy penurunan kadar gula darah yang bermakna pada responden yang melakukan senam rutin selama 4 minggu.

\section{DAFTAR PUSTAKA}

1. American Diabetes Association. (2010). Diagnosis and classification of dibetes mellitus. Diambil dari buku ajar IImu Penyakit Dalam Edisi III Jilid IV Jakarta: Pusat Penerbitan IImu Penyakit Dalam Fakultas Kedokteran UI.

2. Arikunto, S. (2008). Prosedur Penelitian. Edisi Revisi IV. Cetakan 3. Jakarta : Rineka Cipta.

3. Baequny A, dkk (2009). Pengaruh senam diabetes mellitus terhadap penurunan kadar gula darah pada penderita diabetes mellitus. Jurnal Pendidikan. Surabaya: Yayasan Bhakti Karya.

4. Ilyas, E (2005). Penatalaksanaan Diabetes Melitus Terpadu. Jakarta: FK UI

5. Indriani, P.dkk. (2007). Pengaruh Latihan Fisik: Senam Aerobic Terhadap Penurunan KGD pada Penderita DM Tipe 2. Penelitian di Wilayah Puskesmes Bukateja, Purbalingga.

6. Nursalam. (2008). Konsep \& Penerapan Metode Penelitian IImu Keperawatan, Jakarta: Salemba Medika

7. Putra, Dwi (2010). Efek Senam Diabetes Terhadap Glukosa Darah Sewaktu dan Tekanan Darah pada Anggota Persadia Putat Jaya Dengan DM Tipe 2. Skripsi Fakultas Kesehatan Masyarakat Universitas Airlangga

8. Riyadi dan Sukarmin (2008). Asuhan Keperawatan pada Pasien dengan gangguan Eksokrin dan Endokrin pada Pankreas. Yogyakarta: Graha Ilmu

9. Setiadi. (2007). Konsep \& Penulisan Riset Keperawatan.Yogyakarta : Graha IImu

10. Santoso, Mardi. (2010). Senam Diabetes Indonesia Seri 5 Persatuan Diabetes Indonesia. Jakarta: Yayasan Diabetes Indonesia (YADINA)

11. Sudirman. (2009). Pengaruh Senam Diabetes Melitus Terhadap Penurunan Kadar Gula Darah Pada Penderita Diabetes Melitus. Jurnal IImu Keperawatan Politeknik Kesehatan Depkes Semarang

12. Sudoyo, A.W.dkk. (2007). IImu Penyakit Dalam Edisi IV. Jakarta: Pusat Penerbita Ilmu Penyakit Dalam Fakultas Kedokteran UI

13. Sumarni (2008). Prosedur Senam Diabetes, dalam Artikel Nursing Keperawatan Community.Diunduh Mei 2012 melalui www.persadia.html

14. Soegondo, S.dkk. (2009). Penatalaksanaan Diabetes Melitus Terpadu. Jakarta: FK UI

15. Suyono, S. (2007). Diabetes mellitus di indonesia. Buku ajar ilmu penyakit dalam jilid III. Jakarta: Pusat penerbit Departemen Penyakit Dalam FK UI 